University of Chicago Law School

Chicago Unbound

Journal Articles

Faculty Scholarship

1983

\title{
Dissenting Opinions by Supreme Court Justices in Federal Income Tax Controversies
}

Walter J. Blum

Follow this and additional works at: https://chicagounbound.uchicago.edu/journal_articles

Part of the Law Commons

\section{Recommended Citation}

Walter J. Blum, "Dissenting Opinions by Supreme Court Justices in Federal Income Tax Controversies," 82 Michigan Law Review 431 (1983).

This Article is brought to you for free and open access by the Faculty Scholarship at Chicago Unbound. It has been accepted for inclusion in Journal Articles by an authorized administrator of Chicago Unbound. For more information, please contact unbound@law.uchicago.edu. 


\title{
DISSENTING OPINIONS BY SUPREME COURT JUSTICES IN FEDERAL INCOME TAX CONTROVERSIES
}

\author{
Walter J. Blum*
}

As I muse over the Supreme Court's pronouncements on federal income tax controversies, I have come to wonder about the function of analysis in dissenting opinions. Regardless of the merit of a minority analysis, occasionally I am unable to discern how its publication can possibly contribute to advancing the operation of our extraordinarily complex income tax system. The analysis of a dissenter may, indeed, sometimes cause needless confusion on the part of lower courts, tax advisors and tax gatherers. Much of the confusion could be eliminated, producing a tax world at least marginally better off, I believe, if dissenters generally adhered to these few guidelines in writing opinions:

(1) In dealing with a controversy involving narrow questions of statutory interpretation, little is to be gained by presenting a detailed analysis of an interpretation differing from that adopted by the majority;

(2) In explaining the basis of a dissent, either a summary type of analysis or a citation to some lower court opinion usually is all that is needed, except in situations calling into issue a general rule or one that is judicially made;

(3) In setting forth an analysis, the use of footnotes to make points is normally not a helpful practice;

(4) In adjudicating between competing analyses presented by parties to the controversy, it is unwise to suggest yet another possible solution to the problem at hand;

(5) In dissenting to opinions that turn on technical conclusions, exploration of broader issues is seldom appropriate.

My reflections on these guidelines have led me to reexamine the analysis contained in the dozen or so analytical dissenting tax opinions that have been filed during the last five terms of the Court. My plan is to consider these opinions chronologically in order to explore the functions that might be served by analysis offered in tax dissents and to determine how frequently dissenters actually serve these functions. My tentative conclusions are not wholly comforting.

* Wilson-Dickinson Professor of Law, University of Chicago Law School. J.D., 1941, University of Chicago. - Ed. 


\section{United California Bank v. United States ${ }^{1}$}

In United California Bank, the Court considered a narrow question involving computation of the "alternative tax" by trusts and estates. Under the Code provisions in effect during the years in question, 2 the "normal" tax calculation was to be made by adding $50 \%$ of excess long term capital gains (defined as net long term capital gains in excess of net short term capital losses) to ordinary income and applying to that total the regular graduated rates. An "alternative" tax was to be used, however, if its formula produced a lower amount. The alternative was to be computed in two steps: first, apply the regular rates to taxable income reduced by $50 \%$ of the excess capital gain; and second, add to that partial tax a flat $25 \%$ tax on excess capital gain. Other statutory rules permitted a trust or an estate a deduction for distributions to taxable beneficiaries or an exclusion from income for distributions to tax-exempt beneficiaries. The question presented by the case was whether an estate which had excluded from taxable income that portion of its excess capital gain set aside for charity, was also entitled to reduce its excess capital gain by that same portion in computing the alternative tax. If that reduction was improper, the normal tax would govern, and the amount set aside for charity would have the effect of offsetting capital gains otherwise taxed at the special low rate; if it was proper, the alternative tax would govern, and the charitable set-aside would in effect offset ordinary income of the estate otherwise subject to tax at the regular rates.

Six justices ${ }^{3}$ held that in computing the alternative tax the flat $25 \%$ rate was to be applied to excess capital gain figured after leaving out of account the portion of the gain set aside for charity. The majority acknowledged that this result seemed to be incongruous with a literal reading of the statutory provision mandating that, in computing the normal tax of a fiduciary, the 50\% deduction for capital gains was to be reduced to reflect distributions to taxable parties. But the majority thought that the alternative tax prescription called for a different outcome in view of another provision in the Code that mandated the exclusion from fiduciary taxable income of amounts set aside for tax-exempt entities. The majority in effect equated distributions to taxable parties with set-asides or distributions to nontaxable

1. 439 U.S. 180 (1978).

2. Throughout this Article all statements about the law refer to the rules and sections of the Internal Revenue Code in effect during the tax years in controversy.

3. Chief Justice Burger and Justices Brennan, Marshall, Blackmun and Powell joined in the Court's opinion, which was delivered by Justice White. 
parties. In reaching that conclusion, the majority rejected the argument that different treatment of the two situations could be inferred from the manner in which the conduit aspect of the underlying tax structure worked: a deductable distribution to a taxable person would show up as taxable income for the distributee, whereas a distribution to a charity would not. But little could be made of this argument, the majority suggested, considering that in various other circumstances the reduction in fiduciary tax would not be balanced under the conduit notion by an increase in tax on the taxable beneficiary.

In a fairly long dissent ${ }^{4}$ Justice Stevens, with whom Justices Stewart and Rehnquist joined, contended that the majority had distorted the plain meaning of the statute. Everyone agreed that in computing the normal tax the full excess capital gain was taken into account and then reduced by 50\%; any deduction or exclusion for a capital gain distribution would thus serve to partially offset otherwise favorably taxed capital gains. A parallel result should have been reached under the alternative tax, Stevens argued, as the necessary consequence of using the same definition of an "excess" capital gain for purposes of both the normal and alternative taxes. With respect to both provisions, the statute itself defined "excess" as being net long term capital gain in excess of net short term capital loss. Were that definition applied rigorously, fiduciaries in high tax brackets, making distributions of capital gains to charities, would not enjoy a special benefit - resembling a kind of double counting of a reduction - denied to all other categories of taxpayers.

I readily concede that the dissenters had good reason to indicate in general why they disagreed with the majority opinion, raising as they did questions of statutory interpretation. But what interest is served by a rather detailed analysis of their position? The Court was called upon to decide a very technical issue: how is the alternative tax to be computed under agreed sharply defined circumstances? Once the answer was given in clear terms, the Court had discharged its function. It would be most unfortunate if the dissenting analysis were considered by some tax advisors to be an invitation to relitigate the issue. That analysis, moreover, cannot be of influence or help in resolving other tax controversies of a related nature. There is no broad tax "principle" embodied in either the majority or minority opinion that conceivably might control in other areas of tax law. The dissenting analysis is surely not needed to prod Congress into

4. 439 U.S. at 200. 
amending the statute so as to undo the majority position: the Treasury is better equipped to wage that battle. Nor can I see how the minority analysis clarifies the outcome announced by the majority.

The minority analysis does, however, produce a disconcerting side effect. Included in the majority opinion is a long and complex footnote explaining a weakness detected in the dissenting analysis. ${ }^{5}$ The footnote is a challenge to the reader. Studied by itself or in the context of only the majority opinion, it is virtually impossible to understand. At the very least it requires that the reader first comprehend the minority analysis and then parse the responsive note in light of the majority's own analysis. The whole exercise is frustrating. When one has completed this tortuous course, the line of reasoning in the majority opinion becomes more obscure and less persuasive. I cannot believe that such a display of ping-pong technique adds to the dignity of the Court or elevates the status of its opinions.

In retrospect, the minority would have made a sounder contribution by either composing a paragraph or two summarizing the basis for its conclusion or merely referring to the opinion of the Tax Court that had adopted the main argument of the government.

\section{National Muffler Dealers Association v. United States 6}

From the inception of the modern income tax system in 1913, the statute has conferred tax-exempt status on business leagues, chambers of commerce and boards of trade not organized for profit and whose earnings do not inure to the benefit of private individuals. The term "business leagues," unlike chambers of commerce and boards of trade, has no common usage. The first Treasury Regulation on the subject, issued in 1919, defined a business league broadly and stated that its work need not be similar to that of a chamber of commerce or a board of trade. Ten years later, the regulation was changed to reflect the principle that Congress must have grouped the three terms together to indicate that a business league is an organization of the same general class as the other two. Thus, the business league's activities had to be "directed to the improvement of business conditions of one or more lines of business as distinguished from the performance of particular services for individual persons." "Line of business" by and large has come to be interpreted to mean either an entire industry or all components of an industry within a geographic

5. 439 U.S. at 192 n. 13 .

6. 440 U.S. 472 (1979). 
area. Under this test, an organization devoted to a particular product at the expense of others in the industry would not qualify for a business league exemption.

The validity of the line of business test was put into issue by an association composed of franchised dealers who sold the brandname products of a single manufacturer of automobile mufflers. The association sponsored group insurance programs, held an annual convention, published a newsletter for members and negotiated with the manufacturer to change the terms of the standard dealer franchise and of the parts replacement contract entered into with customers.

The Supreme Court took the muffler case in order to resolve a disagreement between the circuit courts. The appellate court had held against the muffer dealers' association, finding that the line of business test was a reasonable interpretation of the statute and that the regulation was consistent with the intent of Congress in grouping the exemption for business leagues with that for chambers of commerce and boards of trade. ${ }^{7}$ A different court of appeals had reached the opposite result in a case involving a comparable organization composed of members who bottled and distributed a brandname soft drink, holding that the test was too restrictive. ${ }^{8}$ Six members of the Supreme Court upheld the regulation. ${ }^{9}$ After tracing in detail the history of the statute and the regulation, the majority decided that the line of business test was a reasonable implementation of congressional intent in exempting business leagues.

The minority opinion of Justice Stewart, in which Justices Rehnquist and Stevens joined, is composed of only three sentences. ${ }^{10}$ It accepts substantially the reasoning of the court of appeals in the bottlers' association case. Additionally, it notes that the initial interpretation of the statute embraced by the regulations was exactly the opposite of the version governing the tax years in question. Finally, it states that the earlier version is strong evidence of the understanding of the meaning of the law at the time of enactment.

I regard this dissent as wholly fitting, in keeping with the guidelines suggested at the outset. Because the disagreement between the circuits had been clearly resolved by the majority, there was no need

7. National Muffler Dealers Assn. v. United States, 565 F.2d 845 (2d Cir. 1977), affd, 440 U.S. 472 (1979).

8. Pepsi-Cola Bottlers' Assn. v. United States, 369 F.2d 250 (7th Cir. 1966).

9. Justice Blackmun delivered the Court's opinion, in which Chief Justice Burger and Justices Brennan, White, Marshall and Powell joined.

10. 440 U.S. at 489. 
for the minority to go into greater detail in explaining the basis for its dissent. Anyone interested in the strength of the position rejected by the Court can obtain ample instruction by turning to the analysis offered in the court of appeals' majority opinion in the bottlers' association case.

\section{United States v. Euge ${ }^{11}$}

Under section 7602 of the Code the Internal Revenue Service, as designate of the Secretary of the Treasury, is authorized to summon individuals to appear and to produce such books, papers, records or other data, and to give testimony under oath, as may be relevant or material to an inquiry being conducted. At issue in Euge was whether the statutory authorization included the power to compel the execution of handwriting exemplars. A revenue agent, investigating an individual who had not filed tax returns, had issued a summons to obtain the exemplars after discovering a large number of bank accounts that he had reason to believe were being maintained under aliases to conceal that person's taxable income. The court of appeals held that authority to compel the exemplars was lacking.

A majority of six on the Supreme Court reached the opposite result without leaving any traces of doubt. ${ }^{12}$ The conclusion was supported on several grounds. First, at common law the duty to appear and give testimony had traditionally encompassed a duty to provide some forms of nontestimonial physical evidence, including handwriting exemplars. Second, the authority claimed by the Service under the statute was necessary for the effective exercise of its enforcement responsibilities. Finally, compelling handwriting exemplars was entirely consistent with the statutory language and was not in derogation of any constitutional rights or countervailing policies enunciated by Congress.

In a one-paragraph dissent Justice Brennan, ${ }^{13}$ joined by Justices Marshall and Stevens, argued that the Service, unlike common-law courts, had only such summons authority as was given to it by Congress. Congress did confer authority to compel testimony. But nothing in the statutory language or legislative history in any way suggested that the obligation to give testimony included an obligation to create handwriting exemplars - which even the majority conceded are nontestimonial in nature.

11. 444 U.S. 707 (1980).

12. Justice Rehnquist delivered the Court's opinion, in which Chief Justice Burger and Justices Stewart, White, Blackmun and Powell joined.

13. 444 U.S. at 719. 
This dissent not only succinctly states the minority position, but can be viewed as serving another function. In the future, especially as technology develops, the Service might seek to compel production or creation of other forms of nontestimonial evidence. The dissenting opinion can be seen as a caution to the tax world and to the courts that the statutory grant of summons authority is not without boundaries.

In a separate brief dissent ${ }^{14}$ Justice Marshall, building on a theme he has long espoused, urged that requiring a person to provide handwriting exemplars is prohibited by the fifth amendment privilege against compulsory self-incrimination. I believe it is always appropriate for a Justice to note his views on constitutional doctrine. Compared to construing the tax statute, which Congress can and often does modify, in dealing with the Constitution a good deal more flexibility on the part of courts over the years is to be expected.

\section{Prince Edward School Foundation v. United States ${ }^{15}$}

Justice Rehnquist, with whom Justices Stewart and Powell joined, dissented from the denial of a petition for a writ of certiorari. The petitioner was a nonprofit private school foundation that had once been classed by the Internal Revenue Service as an educational organization entitled to tax-exempt status, contributions to which qualified for deduction by the donors. The Service announced that it would no longer recognize the tax-exempt status of any private school unless it adopted and administered a nondiscriminatory admissions standard. To implement this policy the Service required a school seeking tax-exempt status to publicize its nondiscriminatory admissions standard. The petitioner, which retained and taught its belief that racial segregation is desirable, claimed it had a nondiscrimination policy but had never publicized it. The student body contained no blacks. A district court upheld the Service's determination that the school was not entitled to tax-exempt status, concluding first that the school had not met the burden of establishing that its policy was to admit blacks on the same basis as persons of other races, and further, that an inference that the school administered a racially discriminatory policy could be drawn from circumstances surrounding the school's establishment and later conduct.

The dissenting opinion urged that the case presented questions of

14. 444 U.S. at 720.

15. No. 79-1622 (D.C. Cir. June 30, 1980) (per curiam order), affg. 478 F. Supp. 107 (D.D.C. 1979), cert. denied, 450 U.S. 944 (1981). 
widespread importance that should be heard by the Court. It argued that the validity of the announced administrative requirement of a racially nondiscriminatory admissions policy was not apparent from a reading of the statutory exemption provision. The Service had never explained why discrimination based on race was a bar to exemption while discrimination based on religion apparently was not. Taking into account the ordinary meaning of the controlling statute, the existence of authority to issue the pertinent administrative position was questionable. Moreover, assuming that such authority existed, the school had not had the opportunity to demonstrate the sincerity of its asserted open admissions policy.

This analysis by the minority seems fully appropriate under the circumstances. The refusal of the Court to hear the particular case did not settle the law. Other cases might later arise that would challenge the validity of the position implemented by the Service. ${ }^{16} \mathrm{~A}$ decision by the Supreme Court to hear such a case would not be equivalent to a change in its interpretation of the tax statute. The analysis in the dissent can be understood as a step in a continuing dialogue as to whether, and in what situation, the Court will turn its attention to the relationship between tax exemption for schools and discrimination between races in admitting students to a school.

\section{HCSC-Laundry v. United States ${ }^{17}$}

Various types of organizations receive tax-exempt status under section 501 of the Code. Subsection (a) of that section provides that organizations described in subsection (c) are exempt from taxation. Subsection (c) states that among the organizations referred to in subsection (a) are those organized and operated exclusively for a charitable purpose, whose earnings do not inure to the benefit of private parties. Subsection (e), an amendment to section 501 dealing only with cooperative hospital service organizations, provides that such an organization is to be treated as organized and operated exclusively for a charitable purpose if it is confined solely to rendering certain listed services for exempt hospitals, each of which could have performed the services on its own behalf sheltered by the umbrella of its subsection (a) exemption. In the case being litigated, a nonprofit organization operated a hospital laundry for a qualified group of exempt hospitals. Laundry services, however, were not among those services listed in subsection (e). At issue was whether such an

16. See Bob Jones Univ. v. United States, 103 S. Ct. 2017 (1983); note 41 infra and accompanying text.

17. 450 U.S. 1 (1981) (per curiam). 
organization was exempt from tax on the difference between its revenues and expenses, a question on which several courts of appeal had split.

In a per curiam decision, the Court held that cooperative hospital laundries could not qualify for an exemption. Two reasons were advanced in support of the result. One was that, in accordance with a basic principle of statutory construction, a specific provision - here subsection (e) - controls over a general provision, such as subsection (c), particularly when the two are interrelated and closely positioned in the statute. The other reason was the surrounding legislative history. When Congress was considering proposed subsection (e), some senators sought to include laundry operations in the list of services that a cooperative hospital service organization could provide and still maintain its exempt status. This move was rejected at the urging of commercial interests, and it was then made clear in the debate that provision of laundry services would cause denial of exempt status under the new provision. Years later a proposal to add laundry services to the list in subsection (e) was defeated on the floor of the Senate.

Justice Stevens wrote a dissenting opinion of considerably greater length than the majority's per curiam opinion. ${ }^{18} \mathrm{He}$ urged that when the statute was read against the background of the history underlying the governing law, or even when read in isolation, its plain language entitled the laundry cooperative to an exemption. His analysis is built on the observation that, prior to enactment of subsection (e), the leading decision had found that nonprofit hospital purchasing - and, by analogy, laundry - cooperatives qualified for exemption under the general language of subsection (c). There was absolutely no evidence that the later statute, containing the specific list, was intended to withdraw any benefits already available under the earlier act. To infer such a result from the fact that the new provision was located close to the older provision would be a distortion; and the interrelatedness of the two subsections does not substitute for analysis of the problem. The new statute, Justice Stevens concluded, was plainly intended only to extend certain benefits to some taxpayers.

Of what possible utility is this careful and elaborate minority analysis? The per curiam opinion left no doubt that nonprofit hospital cooperative laundries could get tax exemption only if Congress so provided by amending the statute. Congress had actively looked

18. 450 U.S. at 8. 
into the area twice in the not-too-distant past. There is not the slightest suggestion in the dissent that organizations other than laundries might be affected by the holding that subsection (e) limited the types of hospital service entities that might otherwise gain exemption under the broader subsection (c). The exercise in the dissent seems overdone, especially since numerous courts of appeals, in opinions finding in favor of an exemption for hospital laundries, had already made most if not all of the same points. The dissent serves neither to clarify nor to affect the scope of the majority position.

The dissent may be read, however, as a protest against summary disposition by the Court of cases that are more difficult to decide than first impressions might suggest. In that event the elaborate dissent can be taken as a kind of demonstration directed against too wide a use of the per curiam route - a protest that surely serves an important function. But I think such an explanation of the dissent is strained. While the opinion starts by objecting to summary disposition as being ill advised (and it might be noted that Justice White also dissented and would have set the case for plenary consideration), that orientation is soon lost in the detailed treatment of the particular problem under review. By the time the reader has worked through the opinion to its end, the overwhelming theme is the tax status of nonprofit hospital laundry cooperatives. The message concerning summary dispositions is almost sure to be heard only as a minor note.

\section{United States v. Swank ${ }^{19}$}

The propriety of a Service interpretation of the depletion allowance was at issue in Swank. By statute, the owner of an economic interest in a mineral deposit was allowed an elective deduction from taxable income, measured as a percentage of gross income derived by the owner from transactions that exhaust the mineral. The language of the governing statute did not indicate that this deduction was in any way tied to the minimum duration of the taxpayer's interest in the mineral deposit. A Treasury Regulation of long standing merely required that a taxpayer seeking to elect the deduction have an "economic interest" in the mineral in place. Such an interest was defined as being possessed whenever "the taxpayer has acquired by investment any interest in mineral [sic] in place . . . and secures . . . income derived from the extraction of the mineral . . . to which he

19. 451 U.S. 571 (1981). 
must look for a return of his capital."20 Possession through a contractual arrangement of a mere "economic advantage" derived from production, however, was not regarded as an economic interest. In interpreting this regulation the Service had concluded that the duration of a leasehold was a critical factor, holding that a lease revocable on short notice did not create a sufficient economic interest to justify the taking of the elective depletion allowance.

The cases in controversy concerned coal mining leases, in force for relatively long periods, allowing the lessee to sell the output at whatever price it could obtain, but subject to termination by the lessor on thirty days notice. Seven Justices agreed that the lessee was nevertheless entitled to the percentage depletion deduction. ${ }^{21}$ The majority opinion stressed the fact that percentage depletion, which provides a special incentive for engaging in the mineral extraction business, is in no way tied to recouping any capital investment, but rather is based on revenue derived from disposition of the mineral encompassed by the economic interest. The majority also emphasized that denying the depletion allowance to a lessee whose legal interest is subject to cancellation on short notice would result in complete loss of that allowance, inasmuch as the lessor is in no event entitled to take a depletion deduction predicated on its royalties. In support of this conclusion, the majority argued that it would be unfair to deny the lessee a tax benefit available to competitors who, being in a stronger bargaining position, were able to negotiate leases without accepting the risk of quick termination. And, most important for the majority, no rational basis had been suggested for linking the depletion deduction with the duration of the period during which the lessee had the right to mine the coal. If it was sound policy to authorize a special tax benefit for mining a seam of coal to exhaustion, that policy would be equally sound whether the entire operation was conducted by one taxpayer over a prolonged period or by a series of taxpayers operating over successive shorter periods.

Justice White, joined by Justice Stewart, filed a fairly extensive dissent to express a "simple" disagreement with the majority view. ${ }^{22}$ The Court's duty, he contended, was to determine whether the Service's interpretation of the statute was a reasonable one, and not to speculate on who deserved an allowance. The Court had long recognized that recoupment of investment underlay the concept of a de-

20. Treas. Reg. § 1.611-1(b) (1983).

21. Chief Justice Burger and Justices Brennan, Marshall, Blackmun, Powell and Rehnquist joined in the Court's opinion, which was delivered by Justice Stevens.

22. 451 U.S. at 585. 
pletion allowance, and this fundamental theory had remained intact, even though the elective method of calculating the deduction had for convenience's sake been altered and was no longer tied to invested capital. Given the early precedents, Justice White concluded, there was clearly a reasonable basis for the regulation. The Service's consistent interpretation of its own regulation was entitled to deference, especially because the interpretation involved the application of terms expressly used in the regulation; moreover, that interpretation had been accepted by a majority of lower courts that had considered the question. Under these circumstances, it was not unreasonable for the Service to class a lease terminable on thirty days notice without cause as insufficiently long to create an economic interest within the meaning of the regulation.

Is there need for an analytical dissenting opinion in this situation? The main thrust of the dissent surely deserves an airing: there frequently is tension between the view that courts should uphold a Treasury Regulation, especially if reinforced through consistent interpretation by the Service, and the view that courts should be guided by their own analyses of the issues. What is disconcerting about this opinion, however, is that the dissent is not content to establish the reasonableness of the regulation. A good deal of the analysis apparently seeks to undermine or refute the reasoning of the majority.

This attack on the majority reasoning is forcefully illustrated by a long footnote that is only remotely if at all connected with an effort to support the official position of the Service..$^{23}$ The footnote focuses on the majority's observation that the depletion allowance is lost to taxpayers altogether if the lessee is unable to claim the deduction. This observation is misleading, contends the minority. While it is correct that the lessor cannot claim a depletion deduction for sales of coal made by the lessee, it does not follow that the lessor is denied a tax benefit in these circumstances. If the lessor later sells its interest in the coal seam at a profit, the capital gain on the sale is smaller because no depletion allowance was ever available to the lessor. The mechanics behind this result are easy to state: had the lessor been able to claim a deduction for depletion, the lessor's basis would have been reduced thereby, and its capital gain on the sale would then be correspondingly larger.

Making points such as this may seem worthwhile, especially if correct. But it is well to remember that those in the tax world are

23. 451 U.S. at 593 n.3. 
most likely already familiar with these relationships. No doubt the minority's point does weaken the technical argument presented by the majority. In the face of a seven-to-two majority, however, nothing of value emerges from exposing the technical flaws in the majority opinion. In my judgment, the analysis of the minority would have been more appropriate if it had been confined to explaining why the administrative regulation and its implementation were reasonable interpretations of the statutory language, and therefore deserving of Court approval.

\section{Kolom v. Commissioner ${ }^{24}$}

Justice Powell alone dissented from the denial of a writ of certiorari. The controversy involved application of the minimum tax provisions to specially treated stock option arrangements for the benefit of an employee and director of the corporation whose stock was the subject of the options. By exercising his options, the option holder had bought shares at prices far below the prevailing market. He held the shares for six months knowing that under the Securities and Exchange Act he was not free to take down his gain by sale during that period without incurring a penalty. After six months had. elapsed, the market price of the shares was markedly lower than at the date the options were exercised. Under the regular tax rules, the exercise of specially treated options did not result in any compensation income; instead, tax was deferred until the stock acquired through the options was sold and at that time any gain qualified for tax at capital gain rates. The minimum tax, however, did apply to the spread between market price and option price on the date of exercising an employee option. The court of appeals ruled that in the controversy at hand this spread was picked up under the minimum tax, despite the fact that the taxpayer could not legally have realized that gain.

Justice Powell urged plenary consideration of the case by the Court because the lower court's interpretation of the statute, based on a Treasury Regulation, produced a degree of unfairness that could not have been intended by Congress. His argument, in essence, was that this minimum-tax version of the compensation-attime-of-exercise principle was applicable only to stock options that did not qualify for the special deferral and capital gains treatment under the regular income tax. It would be a distortion of the structural scheme of the statute to apply the same version of the principle

24. 454 U.S. 1011 (1981), denying cert. to 644 F.2d 1282 (9th Cir.). 
to options that did qualify for the special treatment since the main purpose of the special rule was to encourage corporate employees to buy and hold stock in the companies for which they work. To carry out this purpose Congress must have intended, in the case of options qualifying for special treatment, that the minimum tax have a lesser reach. That reach would pick up not the difference between option price and stock market value at exercise date, but rather the spread at that time between option price and a constructed market value that took account of restrictions imposed on the employee, including those under the Securities and Exchange Act, which served to limit saleability of the shares acquired by way of the options.

I again acknowledge that it is not unreasonable for a Justice to explain why a lower court position should be examined by the Court. But it would be unfortunate to overload the reports with dissents from denials of certiorari in substantive tax controversies. The strongest case for publishing such a dissenting analysis is present when the vote for granting the petition falls just short of the needed number; when the issue in controversy is broad in the sense that it is likely to arise in litigation involving other taxpayers; and when there is reason to believe that resolution of the issue has an impact on other related circumstances. A well-phrased dissenting analysis might then play a part in mustering the votes needed to get the issue before the Court sometime in the future. The weakest condition for publication is illustrated by the case that gave rise to the dissent by Justice Powell. He was the sole dissenter in a controversy that can only be marked as relatively unimportant in the vast'array of rules in the tax world. The issue in question concerned the minimum tax, not the regular income tax. The issue was likely to remain highly confined because most employees holding stock options that qualify for special treatment are not under the constraints of the Securities and Exchange Act. It is not enough to justify an opinion dissenting from a denial of certiorari on the ground that the result reached by the lower court is unfair: most people familiar with the tax area believe that countless aspects of the income tax are unfair. Nor should too much weight be placed on the argument that the Service failed to carry out the intention of Congress. That contention is at the root of much controversy over tax rules, as a quick glance at the agenda of lower courts will reveal. I think the Supreme Court would be well advised to weigh it lightly in the balance when considering petitions for certiorari. Only in the most unusual cases does it deserve to be memorialized in an opinion of dissent on the certiorari question. 


\section{United States v. Vogel Fertilizer Co. ${ }^{25}$}

The Code limited a controlled group of corporations, which included a brother-sister controlled group, to a single exemption under the corporate surtax. A brother-sister controlled group was defined as two (or more) corporations if five or fewer stockholders - constituting the shareholder group - satisfied both a 50\% and an $80 \%$ test. Under the first test, at least 50\% of all the stock in each corporation had to be owned by stockholders in the group who had identical amounts of holdings in each of the two corporations. Under the second test, at least $80 \%$ of all the stock in each of the two corporations had to be owned by members of the group. The statutory language did not state whether, in applying this second test, the $80 \%$ stock interest had to be composed exclusively of shares owned by those who were stockholders in both corporations. A Treasury Regulation took the expansive position that the test was met if members of the group owned the prescribed fraction singly or in combination. Courts of appeals and the Court of Claims divided sharply on the validity of this statutory interpretation.

Seven Justices of the Court agreed that the regulation could not be sustained, partly because of the statutory language. ${ }^{26}$ The majority opinion pointed to the phrase "brother-sister controlled group" and argued that, inasmuch as this connoted a close horizontal relationship between two corporations, the statutory language was less in harmony with the regulatory interpretation than with the alternative position. But the opinion mainly stressed the legislative history, which the majority thought resolved any ambiguity in the statutory language and made it plain that the regulation was not a reasonable interpretation. Assembling pieces from that history, the majority found that Congress had adopted the five or fewer shareholder threshold to replace an older definition that limited brother-sister corporations to entities in which one person owned $80 \%$ of the shares in each, and that, in doing so, Congress intended that the $80 \%$ requirement be the primary test for defining relationships between two corporations. The 50\% test was then added to ensure that the broader definition was confined to cases in which the brother-sister corporations were, in fact, actually controlled by the group of five or fewer stockholders as one economic enterprise. Thus, the majority concluded that the $50 \%$ requirement dealt with shareholders in the

25. 455 U.S. 16 (1982).

26. Chief Justice Burger and Justices Marshall, Powell, Rehnquist, Stevens and O'Connor joined in an opinion delivered by Justice Brennan. 
group to the extent they had matched positions in the two corporations, while the $80 \%$ requirement would be satisfied if the same group of five or fewer owned at least $80 \%$ of the shares of each corporation, regardless of the size of the holdings of each person.

Justice Blackmun, joined by Justice White, dissented ${ }^{27}$ on the ground that, although the majority defended a possible interpretation of the statute, it totally failed to establish that the interpretation contained in the regulation was incorrect. Because both the statutory language and the legislative history were ambiguous, the Court should have deferred to the administrative interpretation if it was reasonable.

The minority argued that the administrative interpretation was reasonable by showing it was not unreasonable. On its face, the statute, which is silent as to whether each member of the group must own stock in each corporation, could be read as suggesting only that the total number of shareholders considered in relation to both tests may not exceed five, and as prescribing that the identical ownership requirement applies only to the $50 \%$ test. The legislative history was not necessarily conclusive in view of the fact that a key Treasury document, relied on heavily by the majority, was itself ambiguous. The document, which declared that the $80 \%$ test was satisfied if the group as a whole owned at least $80 \%$ of the shares of each corporation regardless of the size of the individual holdings of each person, suggested that the critical inquiry was whether a given set of five owners satisfied both tests, not whether each individual in the set owned stock in each corporation. Under these conditions, the minority urged, the interpretation in the regulation could not be unreasonable.

What contribution to tax law can this minority exercise make? On initial impression, it might appear that an important general proposition is being asserted: the courts, in reviewing an interpretive regulation, should focus on whether the Treasury position is incorrect in the sense of being unreasonable or meaningless rather than on whether a different interpretation is more attuned to the intent of Congress as inferred from the statutory language and history. I submit that these two inquiries will entail the same analysis, differing only with respect to a subjective judgment about the relative strength of the support seen for the competing positions. The majority and minority opinions indeed covered the same ground in examining the

27. 455 U.S. at 35. 
$80 \%$ test for defining brother-sister corporations and took account of the same arguments.

My guess is that all members of the Court would have sustained the regulation had they agreed that the alternative interpretations were equally in harmony with the ambiguous statutory language and history. Conceivably the minority would have sustained the regulation if the administrative position was plausible even though not as persuasive as the competing view. The minority, however, did not take the opportunity to announce such a doctrine, nor would precedent uphold that treatment of interpretive regulations. A more careful reading of the two opinions suggests that the majority found the taxpayer's interpretation more compelling than that offered by the Treasury. In short, the minority thought the sides were even, while the majority thought the scales clearly came down on the side of a looser definition of brother-sister corporations. On my score card, it is not highly instructive to try to account for this difference in judgment.

If these reflections are on the mark, there is reason to doubt the wisdom of presenting a minority opinion that goes beyond a summary statement of the basis for dissent. The majority obviously settled the only statutory interpretation question at issue; it is altogether unlikely that a comparable one will emerge for which this decision will stand as precedent. The minority opinion did not put forward a new or different guide to statutory interpretation. In the end, all the opinion does is attempt to explain why, in the minority's judgment, the interpretation adopted by the Treasury was at least on a par with that urged by the taxpayer. Once that judgment had been stated, the minority opinion need not have done more than back it up with citations to the various lower court opinions that had reached the same conclusion.

\section{Diedrich v. Commissioner ${ }^{28}$}

In each of the two sets of facts considered by the Court in Diedrich, ${ }^{29}$ an individual had made a gift of appreciated property to a close relative on the express condition that the donee pay the gift tax resulting from the transfer. A gift of property that has appreciated in value in the hands of the donor does not bring any part of that appreciation into the taxable income of the donor. The donee of such

28. 457 U.S. 191 (1982), affg. 643 F.2d 499 (8th Cir. 1981).

29. The Supreme Court was presented with two sets of facts because the Eighth Circuit had consolidated two related appeals from the Tax Court. 
property receives no income by virtue of the gift, but inherits the donor's adjusted basis for purposes of computing gain on a later taxable disposition of the asset. At issue was whether the donor realized taxable income to the extent that the amount of gift tax paid by the donee exceeded the donor's adjusted basis in the transferred asset. A circuit conflict had developed on this question.

All but one member of the Court agreed that the donor had realized gain to the extent of the excess. ${ }^{30}$ This conclusion flowed from a well-accepted principle: the discharge by one person of an obligation resting on another is equivalent to a direct receipt of value by that other party because the two alternative arrangements have identical economic consequences. In a gift situation, a debt to the government for the amount of the gift tax is incurred by the donor. The economic benefit to the donor arising from payment of this tax by the donee confers on the donor an economic benefit indistinguishable from the benefit arising from discharge of any other pre-existing obligation. The fact that the gift tax obligation is discharged by way of a conditional gift, rather than from funds derived from a pre-gift sale, does not alter the underlying benefit to the donor. The Court concluded that the Service properly treated the conditional gift as if the donor had sold the entire asset to the donee for the amount of the gift tax, thereby producing a taxable gain measured by the excess of that amount over the donor's adjusted basis in the asset.

Justice Rehnquist dissented ${ }^{31}$ in a short opinion arguing that the discharge of obligation principle was wrongly invoked. That principle assumes, he asserted, that a taxable transaction has taken place, in which event he would have agreed that the principle was relevant in ascertaining the amount of income realized by the benefitted party. In the conditional gift situation, however, the underlying question is whether a taxable transaction has occurred at all. On this issue there had been no demonstration that Congress intended the conditional gift to be treated as a partial sale. The statute clearly provided that although the donor was primarily liable for the gift tax, the donee was also liable, to the extent of the gift's value, should the donor fail to pay the tax. No evidence was introduced that Congress had forbidden the parties from agreeing to have the donee pay the gift tax, on pain of having such an agreement produce a taxable event.

Pinpointing the role performed by this dissenting analysis is a

30. Chief Justice Burger delivered the Court's opinion, in which Justices Brennan, White, Marshall, Blackmun, Powell, Stevens and O'Connor joined.

31. 457 U.S. at 200. 
troublesome task. The analysis does seek to explain the basis for dissent; and it does so in a compressed fashion. These qualities comply with sound standards for a dissenting opinion. But the analysis put forward is unsatisfactory because of poor dovetailing with the majority position. The dissent seems to be saying that the majority failed to establish the major premise of its argument: the donor must have an obligation to pay the gift tax before it can be concluded that payment of that tax by the donee discharges an obligation of the donor. If under the gift tax the donor and donee can by agreement determine who is to pay the tax, and if they decide to put that burden on the donee, it would then seem that in making the payment the donee discharges his own obligation and not that of the donor. From an isolated reading of the dissent, one might infer that the majority failed to understand this crucial relationship.

I think it unhelpful for the minority opinion to undercut the majority analysis in such a manner. The core point in the dissent, I take it, is that there is no evidence that Congress intended to put the gift tax obligation on the donor rather than let the donor and donee decide which of the two is to bear the burden. If this is a correct reading of the dissent, then the challenge is not to the reasoning of the majority, but to the adequacy of its attention to establishing an obligation on the part of the donor to pay the gift tax. The majority opinion does not entirely ignore this issue. It notes that the gift tax is to be paid by the donor and that the donee is liable for the tax, to the extent of the value of the transferred asset, if the donor does not make the payment. Faced with a question whether, under this prescription for paying gift tax, Congress intended the obligation to be primarily that of the donor, the majority opinion surely could have been strengthened by addressing the issue more fully. The format of the dissenting analysis, however, did not tie in neatly enough with the majority opinion to elicit a deeper response to the central question that apparently divided the Court. A shorter and more focused dissent might have served this function better. At least it would have avoided casting unnecessary doubts on the cogency of the majority view which, after all, did firmly decide the substantive tax question being litigated.

Hillsboro National Bank v. Commissioner ${ }^{32}$

The tax benefit rule, a judicial creation codified for certain types

32. 103 S. Ct. 1134 (1983). Hillsboro National Bank was decided together with United States v. Bliss Dairy, Inc. 
of transactions, has been part of the tax structure for many decades. During most of these years the rule was thought to operate as follows: if a cash method taxpayer properly took a tax-reducing deduction for payment of an expense and if, in a later year, an equivalent amount was recovered by the taxpayer because in the light of new events the initial payment turned out not to have been required, then the recovered amount would be taxable as income in the year received. Similarly, if an accrual basis taxpayer properly took a taxreducing deduction for accrual of an expense and if, in a later year, it turned out in the light of new events that the taxpayer was no longer obligated to pay that liability, then the amount of that liability would be income in the year it was cancelled. In the case of both the cash and accrual taxpayers, the income in the later year reflected an increase in net worth resulting from the recovery of value or the cancellation of a liability. During recent years some lower courts had taken a more expansive view of the tax benefit rule. In a few circumstances they held that the taxpayer had income in the subsequent year, even in the absence of any recovery of value or cancellation of a liability, if in that year there occurred an event that was inconsistent with the assumption implicitly made in the earlier year that justified taking the deduction at that time. Such an expanded view was rejected by other lower courts which continued to adhere to earlier precedents.

In Hillsboro National Bank, a banking corporation, in accordance with a special rule in the Code, deducted amounts paid to discharge a state personal property tax levied on individual shareholders of the bank. These amounts were put in escrow because the validity of the property tax was uncertain under a newly amended state constitution. When in a later year the state tax was held invalid, the escrowed funds were, pursuant to state court decree, disbursed to the individual shareholders rather than returned to the bank. The issue framed by these events was whether the bank was taxable in the disbursement year under the tax benefit rule.

In Bliss Dairy, Inc., a corporation in the business of fattening livestock purchased cattle feed, the full cost of which was deducted as a business expense. Almost immediately after the close of its final taxable year, the corporation was liquidated in a manner coming within a Code provision that, generally speaking, treated the liquidation as not triggering taxation to the corporation of gain on its assets. The question in controversy was whether the tax benefit rule nevertheless called for bringing the value of the feed on hand at the time of liquidation into corporate income for that year. 
The majority opinion ${ }^{33}$ disposed of the Hillsboro Nationa! Bank case in a manner that did not implicate the tax benefit doctrine. On the basis of scant and tangential fragments in the legislative history relating to the enactment of the special rule for payments by banks of property taxes of shareholders, the majority held that Congress intended to allow a deduction for the payment regardless of whether the transmitted funds ultimately were used to discharge a liability for tax or were disbursed to shareholders. Presumably the banks would come within the ambit of the tax benefit doctrine only if the funds were returned to them when the state tax was found to be invalid.

In Bliss Dairy, the majority did confront the tax benefit question, there being no escape comparable to that provided by the special statutory rule for banks. It rejected the contention that the tax benefit rule should be confined to cases in which value in the later year is recovered by the taxpayer. Instead, it held that the corporation was taxable on feed owned at liquidation time because the liquidation distribution was "fundamentally inconsistent" with the earlier feed purchase deduction which, presumably, had been premised on the assumption that the feed would be given to livestock being raised by the corporation.

Two dissenting analyses were published - one by Justice Stevens ${ }^{34}$ and the other by Justice Blackmun. ${ }^{35}$ Justice Stevens' dissent quickly accepts Justice Blackmun's analysis of the Hillsboro National Bank problem, concluding that the bank should be taxable under the tax benefit rule as though the funds had been returned to the bank and then paid out as a nondeductible dividend to the shareholders. Most of Justice Stevens' opinion deals with examining the reach of the tax benefit rule. It traces in considerable detail the development of the rule and demonstrates that there had been a high degree of consensus, manifested in several Supreme Court decisions and reflected in actions of Congress, that the rule was activated only through a recovery of value by the taxpayer in a later year. It goes on to point out that, in discarding the recovery of value foundation for the rule and replacing it with an inconsistent events underpinning, the majority made a change that will affect a great number and variety of transactions. The majority's statement of the new rule is so

33. Chief Justice Burger and Justices White, Powell and Rehnquist joined in the Court's opinion, which was delivered by Justice O'Connor.

34. Justice Stevens, joined by Justice Marshall, concurred in the judgment in Hillsboro but dissented in Bliss Dairy.

35. $103 \mathrm{~S}$. Ct. at 1163. 
imprecise, however, that its application will necessarily be surrounded by much doubt. The concept of inconsistent events is not self-defining and the descriptions of the test in the majority opinion are themselves inconsistent and imprecise. Moreover, notes the Stevens analysis, even if the new test is found applicable in a particular situation, the mechanics of its operation are far from clear. Regarding the very situation in Bliss Dairy, the majority failed to indicate what would have to be done if the feed had been purchased in differing quantities in each of several past years, or if the value of a unit of feed was less at the time of liquidation than at the time of purchase, or if, under changing price conditions, the cost of purchasing feed had changed between different years of purchase. For all these and other reasons, the new tax benefit rule is bound to be a greater source of complication than the old. Broad policy changes of the sort being adopted by the majority, concludes the opinion, are better left to Congress.

This is an important dissent. Unlike many tax cases in which the Court takes on the task of interpreting narrow or technical language in the statute, in Bliss Dairy it reconsidered a broad and general rule of judicial origin. The Stevens analysis can be seen as an effort to convince other members of the Court not to overthrow the old understanding as to the boundaries of that rule. But, failing in that goal, it might serve other significant functions as well.

Should Congress ever consider putting more or all of the tax benefit rule into a statutory prescription, the Stevens dissent is a strong reminder that the majority opinion was thought by the minority to be highly flawed, both in its treatment of history and in its failure to assess the weaknesses of the new approach. Not that the minority analysis itself is potent as an argument before Congress; rather, it is a testament that the majority opinion does not deserve to be weighed heavily in reaching a legislative solution. Of greater importance, perhaps, is the message available to lower courts: beware of adopting an overly literal interpretation of the inconsistent events test. There is much need for careful ongoing analysis in fashioning a statement of subsidiary principles that will bring a reasonable degree of coherence to the borderlines of the new doctrine. And there is a subsidiary message: the mechanics for determining just how many dollars are swept into income under the test must be established by way of another subset of rules. These new rules will have to serve as a substitute for old rules under which the recovery amount was easily ascertainable. Perhaps it is unnecessary to add that these 
messages can also assist those who will be responsible for framing tax benefit litigation in the future.

A few aspects of the Stevens opinion detract from the possible roles I can visualize it playing. It relegates to the footnotes some trenchant observations about complexities and ambiguities inherent in the new rule; these points would count more heavily had they appeared in the text. It glosses over a major obstacle to the development of the new rule embraced by the majority opinion: no single guide is furnished for determining when the new tax benefit rule does or does not override a statutory provision that otherwise dictates that the transaction in question will not give rise to recognition of gain. All that the majority advised on this score was that in each of these clashes the courts, in defining the reach of the new rule, will have to work out a result that takes account of the background for enacting the competing statutory nonrecognition provision. On the whole, however, such minor shortfalls do not impair the usefulness or significance of the Stevens opinion.

Justice Blackmun's minority analysis covers both the important issue of defining the scope of the tax benefit doctrine and the narrow issue posed by the special rule governing payment by banks of property taxes of their shareholders. In regard to application of the tax benefit rule, the opinion offers a solution that radically differs from both the old and new versions of the doctrine. It suggests that the problem of inconsistent events occurring in separate tax years might best be dealt with by making a corrective change in the tax as computed for the year in which the deduction was taken. This approach, of course, would be feasible only if the limitations statute did not bar going back to the year of the deduction. Nothing is said about the procedure to be followed if the limitations statute did bar reopening the tax return for the earlier year.

The suggestion that the correction be in the year of deduction is logically defensible but badly misguided, I believe, under the circumstances in which it was offered. The Court had been unusually well informed that the central issue in controversy was whether the recovery of value concept of the tax benefit rule should give way to the inconsistent events springboard. It simply was out of place to flirt with any other principle for dealing with deductions predicated on premises that might later turn out to have been wrong. Members of the Court, in my judgment, should have confined themselves to choosing between the two conceptions of the tax benefit rule that had some support in the precedents and that figured centrally in the contentions of the litigating parties. 
Perhaps no harm results from such excursions in dissenting opinions. I do not share that comforting view. Introduction of a third approach to the problem is a distraction. In the case itself the suggestion drew a long footnote response in the majority opinion - a footnote that made that opinion somewhat more difficult to read. ${ }^{36}$ This freewheeling idea tends to divert attention from practical problems that will be generated by the majority pronouncement on the new tax benefit rule. And the distraction might even blunt the thrust of important and relevant points made in the Stevens opinion concerning the weaknesses of that doctrine and the difficulties that it will engender in the future.

The part of the Blackmun opinion dealing with the special rule for banks that pay the property taxes of their shareholders is of a different nature. The analysis sharply disagreed with the view of legislative intention derived by the majority. In enacting the special rule that gave the banks a deduction, Congress' focus likely and logically was on payment of a property tax, not on the outlay of funds that were never used to satisfy a tax obligation. The Hillsboro case therefore should be treated as presenting a situation that called for application of the tax benefit rule - whether in its old or new form. I regard this aspect of the Blackmun analysis as appropriate for an opinion in dissent. It is a direct challenge to the main foundation of the majority position.

\section{United States v. Rylander ${ }^{37}$}

The controversy in Rylander centered around the power of the courts to compel testimony in tax cases. The respondent was summoned by the Internal Revenue Service to appear before one of its agents and to produce for examination, and give testimony concerning, records of the two corporations of which he was president. When he failed to comply with the summons, the district court enforced it and ordered him to appear before an agent of the Service and produce the relevant records. He appeared but failed to produce the records. In the civil contempt hearing that followed in the district court, the respondent declared that he did not possess the records and had not disposed of them to any other person. That court, after finding that he had failed to introduce any evidence in support of the claim that he did not possess the records, and after affirmatively finding that, as corporate president, he had possession

36. $103 \mathrm{~S}$. Ct. at 1140 n.10.

37. 103 S. Ct. 1548 (1983). 
of the records, held the respondent in contempt. The court of appeals reversed. ${ }^{38}$ It agreed that the government, in a contempt proceeding, meets its initial burden by showing only a failure to comply and the burden then is on the defendant to show in detail why he is unable to comply. But it concluded that the defendant need not meet this burden if he properly claims that his testimony as to the whereabouts of the documents might be incriminating. When the defendant has made a bona-fide fifth amendment claim regarding incrimination, his statement that the documents are not in his possession or under his control is sufficient to satisfy his burden of production. The burden then shifts to the government to introduce evidence showing that the documents in question actually exist and are in the defendant's possession or under his control. After noting that a failure to raise this defense in the enforcement proceeding did not limit the defendant's argument in the contempt proceeding, the appeals court concluded that in the situation at hand the respondent's burden of production had been met if his fifth amendment claim was valid.

All but one member of the Court decided that the contempt citation was valid. ${ }^{39}$ The defense of not having possession or control of the documents could have been raised by the respondent at the enforcement hearing, which is an adversary proceeding. The enforcement order, unappealed from, necessarily contained an implied finding that a lack of possession defense had not been raised or sustained in that proceeding. That defense could not be raised for the first time at the contempt proceeding; in that action the respondent could defend on the ground of lack of possession only if he then was unable to comply. Nor could the respondent successfully justify his refusal to allow cross-examination at the enforcement hearing with the contention that answering such questions might tend to incriminate him. While assertion of the fifth amendment privilege against compulsory self-incrimination may be a valid basis for refusing to answer questions, it is never in itself a substitute for evidence that would assist in meeting a burden of production. A possible failure of proof on an issue as to which the defendant had the burden of proof, concluded the majority, is not a form of compulsion requiring that the burden be shifted from the defendant to the government.

Justice Marshall dissented ${ }^{40}$ on the ground that the majority opinion created a new exception to a basic constitutional right, the

38. 656 F.2d 1313 (9th Cir. 1981), revd., 103 S. Ct. 1548 (1983).

39. Justice Marshall filed the sole dissent to an opinion delivered by Justice Rehnquist.

40. $103 \mathrm{~S}$. Ct. at 1555. 
privilege against self-incrimination. He argued that the district court made no finding that the respondent possessed the documents at the time of the contempt proceeding: it found only that as corporate president he had possession - presumably meaning only past possession, not present possession. Since the district court had not found that the respondent was at the time able to comply with the order to produce the documents, it followed that respondent was held in contempt simply because he invoked the fifth amendment when asked at the contempt proceeding to testify as to the whereabouts of the documents. Had he testified he might have been convicted by his own words.

On one reading, the dissenting opinion fits into the familiar mold of a mild push either to tighten or to relax the ambit of an important constitutional doctrine. The fact that the occasion for expressing views on the doctrine is presented by a controversy concerning taxes is of small significance. The dissent is simply a response to the majority analysis, construed as serving to limit rather than to expand the fifth amendment's protection against compulsory self-incrimination. Because the scope of that protection has fluctuated considerably over the years, there is an understandable reason for members of the Court to seize various occasions to reassert and lobby for their own general orientations regarding the scope of the doctrine - although at times the reiteration of these old themes might become somewhat boring.

On another reading, however, the dissenting analysis is less easy to justify as an entry into the Court publications. The separation between the majority and minority can be seen merely as a very narrow difference over the interpretation to be placed on one aspect of an enforcement proceeding that grew out of a tax investigation. According to the majority, the lower court report showed that the enforcement proceeding implicated and settled the point that, at the time, the respondent had the records in his possession or control. The dissent thought that the report established only that the respondent previously had possession of the records, not that he had them at the moment of the enforcement action. I submit that, in the face of a strong majority stand on the matter in dispute, the case for publishing a minority analysis is weak at best. Surely the circumstances do not offer a strong platform from which to launch a statement about the scope of the fifth amendment protection against compulsory self-incrimination. 
Bob Jones University v. United States ${ }^{41}$

From the outset of the modern income tax, the statute has provided an exemption for not-for-profit corporations and other entities organized and operated exclusively for educational purposes. Before 1970, the Service maintained the position that it lacked authority to deny tax exemption if a school met the particular requirements specified in the statute. In 1970, parents of black children in certain public schools sued to enjoin the Service from according tax exempt status to private schools that discriminated against blacks. ${ }^{42}$ During this litigation, and in the face of a preliminary injunction, the Service revised its long-standing position and adopted the view that racial discrimination was a basis for denying an exemption. Following the close of the litigation, the new Service position was published in a Revenue Ruling stating that a school must be a common-law charity in order to be exempt under the statutory provision, and that schools promoting racial discrimination violate public policy and therefore cannot qualify as common-law charities. The two cases heard by the Court involved colleges that had followed racially discriminatory practices. One had been denied an exemption, the other had had its exemption revoked by the Service.

Eight members of the bench upheld the validity of the Revenue Ruling and agreed that the colleges were not entitled to an exemption. ${ }^{43}$ All but one of the eight took the position that an examination of the exemption provision, undertaken within the framework of the Code and against the background of congressional purposes, revealed unmistakable evidence that entitlement to tax-exempt status depended on the common-law standards for a charity: an institution seeking tax exemption must serve a public purpose and not be contrary to established public policy. The institution's purpose accordingly must not be so at odds with the community conscience as to undermine any public benefit that might otherwise be conferred. Racial discrimination in education is contrary to public policy. Therefore, a discriminating school cannot be viewed as conferring a public benefit within the common-law meaning of a charitable activity. The Service's position that a racially discriminatory private school is not charitable within the common-law concepts reflected in

41. 103 S. Ct. 2017 (1983).

42. See Green v. Kennedy, 309 F. Supp. 1127 (D.D.C.), appeal dismissed sub nom. Carron v. Green, 398 U.S. 956 (1970).

43. Chief Justice Burger delivered the Court's opinion, in which Justices Brennan, White, Marshall, Blackmun, Stevens and O'Connor joined. Justice Powell concurred in the judgment and in Part III of the Court's opinion. $103 \mathrm{~S}$. Ct. at 2036. 
the statute is wholly consistent with what all three branches of government had said prior to 1970 about racial discrimination being a violation of public policy. All eight Justices in the majority agreed that actions of Congress since 1970 left no doubt that the Service reached the correct conclusion in exercising its authority. For a dozen years Congress had been made aware of that conclusion. The failure of Congress to modify the announced position presented an unusually strong case of legislative acquiescence in and ratification by implication of the administrative measure.

Justice Rehnquist dissented ${ }^{44}$ on the ground that, while Congress could deny exemption to educational institutions that racially discriminate, the legisiature had failed to take that action and the Court was not constitutionally empowered to act for that body. The statutory qualifications for exemption of a school, he observed, were drawn with undeniable clarity. Congress had both decided what organizations were serving a public purpose and providing a public benefit and had set forth the characteristics of such organizations. Nowhere was there to be found some additional, undefined public policy requirement. Congress had left it to neither the Service nor the courts to select from or add to the requirements put into the statute - a point of view that the administrative agency had long and consistently embraced before it changed postures in 1970 .

Moreover, according to the dissent, congressional action after that change did not show that the Service had reached the correct result. On the issue being adjudicated, there was only congressional inaction throughout the period, despite all the attention called to matters of racial discrimination. Congress in fact did act to deny taxexempt status to social clubs whose policy statements provided for racial discrimination. This event should have served as a reminder that the legislature is fully aware of how to add a provision making nondiscrimination a requirement for exemption. Until Congress affirmatively changed the statutory rules regarding schools, concluded Justice Rehnquist, the Service was without authority to deny exemptions on grounds of discrimination.

Does this minority analysis perform a useful function beyond explaining the reason for dissent in a controversy that involves strong political overtones? The crux of the dissenting position goes to the propriety - perhaps the constitutionality - of a radical change, made by the Service, in its interpretation of a statutory provision. In the abstract this is an important question for the tax system. If the

44. 103 S. Ct. at 2039. 
Service is empowered generally to change the rules based on a revision of its judgments concerning public purpose and public benefits, the power of the agency may be greatly enhanced. An administration seeking modification of the rules will then be able to buttress its case by arguing that the activities of particular types of organizations are not compatible with newer perceptions of the public interest. Indeed, it was concern over this possibility that led Justice Powell, who filed a concurring opinion, to part company with the majority view. Despite strong words of caution in the majority opinion regarding the Service's authority to adjust the rules to its views of public policy, the approach of the majority possibly could be read someday as conferring broad power on the agency. The dissent (as well as the concurrence) might serve to restrain the Service from attempting to exercise that power apart from situations implicating racial discrimination. Conceivably, the dissent might reinforce a more radical thought: the administrative change in position was not quite proper, but racial discrimination in education is to be treated as one of a kind.

Perhaps the greater significance of the minority analysis goes beyond tax matters. A common question emerging from the structure of our federal government concerns the weight that courts and administrative agencies, in interpreting statutory language, should place upon congressional conduct that does not result in amending the language being interpreted. The majority in the two cases under adjudication asserted that legislative inaction is to be treated as ratification of the change in the Service's position; the minority analysis asserted that inaction is tantamount to a legislative injunction not to alter the rule as framed under the earlier interpretation. The majority can be understood as saying that if Congress does not approve the administrative change, it can amend the statute to reflect the rule that carries out its intentions. The minority seems to be saying that the burden of taking action runs in the very opposite direction: in the face of legislative inaction, the Service is not to change the rule. This is a basic question, one that has arisen in areas outside of taxation, and that undoubtedly will appear again. The analysis of the minority can thus be viewed as bearing on both tax and other issues in years to come.

More likely, however, the analysis will be considered little more than sounds of anguish that the Court chose such very high and broad grounds on which to justify an unusual and unlikely-to-berepeated action of the Service. Whether or not it is more than a protest against the majority's unwillingness to turn back the clock of 
history as to racial discrimination in education, the Rehnquist opinion does not appear to set back our income tax world.

\section{CONCLUSION}

What is to be learned from this review of the various analyses offered in dissenting tax opinions over the past five terms of the Supreme Court? When the Court has decisively interpreted narrow or technical language in the statute, dissenters all too often indulge in lengthy analyses that can only serve to create further confusion. Only when the Court focuses on a judicially made rule or an issue with constitutional implications is a broader dissent appropriate. If dissenters generally adhered to the guidelines set forth at the outset of this Article the tax world would, I believe, be at least marginally better off. 